\title{
Boron Removal in Molten Silicon by a Steam-Added Plasma Melting Method*1
}

\author{
Naomichi Nakamura, Hiroyuki Baba, Yasuhiko Sakaguchi ${ }^{1}$ and Yoshiei Kato*2 \\ ${ }^{1}$ Steel Research Laboratory, JFE Steel Corporation, Chiba 260-0835, Japan
}

\begin{abstract}
Oxidation and removal of boron from molten silicon by a steam-added plasma melting method was investigated as an important part of a sequential metallurgical process for producing high-purity solar grade silicon (SOG-Si) from commercially available metallurgical grade silicon (MG-Si). Experiments were carried out with the mass of silicon per charge varied in the range from 0.6 to $300 \mathrm{~kg}$, corresponding to the laboratory scale to industrial scale. Boron was removed to $[B]<0.1$ mass ppm, which is the permissible boron content for SOG-Si. The deboronization rate was proportional to the steam content, 3.2th power of the hydrogen content of the plasma gas, boron content of the molten silicon, and area of the dimple formed by the plasma gas jet, and was inversely proportional to the mass of the molten silicon. A thermodynamic study showed that preferential oxidation of boron in molten silicon is positively related to higher temperatures, supporting the conclusion that this plasma method, which causes a local increase in the temperature of the reaction surface, is in principle advantageous.
\end{abstract}

(Received November 11, 2003; Accepted January 29, 2004)

Keywords: boron, silicon, plasma, steam, hydrogen, solar grade silicon, metallurgical grade silicon, photovoltaic cell

\section{Introduction}

Photovoltaic power generation in Japan is rapidly gaining popularity, mainly in the housing industry, showing an average annual increase of $30-40 \%$. Solar cells are largely made of crystalline silicon because this material is extremely reliable and has high energy conversion efficiency in converting solar to electric energy. Off-spec silicon from the semiconductor industry is generally remelted for use in crystalline solar cells, but the supply and price fluctuate, depending on conditions in the semiconductor industry. Thus, it was necessary to secure a reliable supply of low-cost silicon material.

Metallurgical grade silicon (MG-Si) can be supplied consistently for solar cell use. However, to obtain the properties required in solar grade silicon (SOG-Si), which includes p-type, 0.005-0.01 $\Omega \mathrm{m}$ and a conversion efficiency of $14-15 \%$, the content of impurities such as boron, phosphorus, iron, aluminum, and titanium in the silicon must be reduced to below the permissible levels shown in Table 1. ${ }^{1-3)}$ With the metallurgical purification method, metallic elements with a low equilibrium partition coefficient are eliminated by directional solidification, ${ }^{1,2)}$ and phosphorus is removed by evaporation, taking advantage of its high vapor pressure. ${ }^{3-5)}$ On the other hand, boron is difficult to remove by either of these two methods because it has an equilibrium partition coefficient of $0.8^{6)}$ and a low vapor pressure similar to that of iron and titanium. ${ }^{7}$

Table 1 Impurities contents in silicon.

\begin{tabular}{cccccccc}
\hline & B & P & Fe & Al & Ti & C & O \\
\hline \multirow{2}{*}{ MG-Si } & $5-10$ & $25-30$ & $\begin{array}{r}1000- \\
1500\end{array}$ & $\begin{array}{c}600- \\
800\end{array}$ & $\begin{array}{c}150- \\
200\end{array}$ & $\begin{array}{c}150- \\
250\end{array}$ & - \\
\hline \multirow{2}{*}{ SOG-Si } & $0.1-0.3$ & $<0.1$ & $<0.1$ & $<0.1$ & $<0.1$ & $<5$ & $<6$ \\
\hline
\end{tabular}

${ }^{* 1}$ This Paper was Originally Published in Japanese in J. Japan Inst. Metals 67 (2003) 583-589.

${ }^{*}$ Present address: Patent \& Technical Information Business Division, Kawasaki Steel Techno-Research Corporation, Tokyo 100-0005, Japan
Oxidation is another possible method of removing boron from a silicon melt. Examples include the use of a mixed gas of steam and argon as an oxidizing atmosphere in the floating zone melting method ${ }^{8)}$ and in plasma gas. ${ }^{9-13)}$ However, with both methods, experiments have been limited to a small scale below $0.6 \mathrm{~kg}$ of silicon.

As discussed in the section of thermodynamics of boron oxidation later, a higher molten silicon temperature causes preferential boron oxidation. It means that increasing the reaction surface temperature by plasma heating is more effective.

In this study, removal of boron from molten silicon by the steam-added plasma melting method was investigated as an important part of a sequential metallurgical process for producing high-purity SOG-Si. Experiments were conducted over a range from the laboratory scale to pilot plant scale in order to obtain data for scaling-up the process and to establish the basic design of a deboronization process for industrial equipment.

\section{Experimental Procedure}

A schematic view of the experimental apparatus for plasma deboronization is shown in Fig. 1. Four types of apparatus were used, and the mass of molten silicon was varied from 0.6 to $300 \mathrm{~kg}$. The silicon was melted by applying plasma gas to silicon in a crucible or by using a high-frequency induction furnace around the crucible. An oxidizing gas, including steam through nozzles, and plasma gas were impinged on the molten silicon. A hydrogencontaining oxidizing gas was used in some cases. In another experiment, the oxidizing gas was injected into the molten silicon through a submerged nozzle.

The experimental conditions are shown in Table 2. Nontransfer type plasma was mainly used, but was also compared with the transfer type (cathode, plasma torch; anode, watercooled copper of the crucible bottom) as shown in II of Table 2. The normal plasma gas was argon, which was compared with a mixed gas of helium or hydrogen. The steam content of the total gas impinged on the molten silicon depended on the size of the equipment and was varied up to 


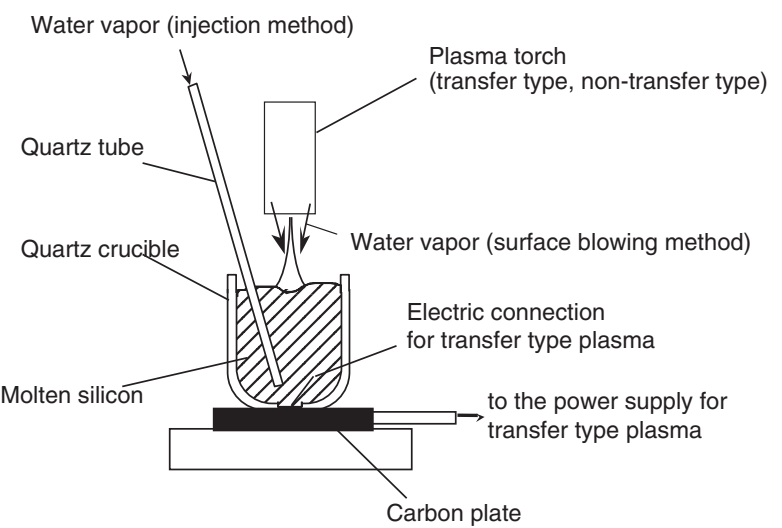

Fig. 1 Schematic diagram of the experimental apparatus for plasma deboronization.

$14.2 \mathrm{vol} \%$. The maximum hydrogen content of the total gas was $55 \mathrm{vol} \%$. The distance from the tip of the plasma torch to the surface of the molten silicon was varied from 0.06 to $0.45 \mathrm{~m}$. A silica crucible was used in all experiments except with the $0.6 \mathrm{~kg}$ silicon melt shown in II of Table 2, in which case a graphite crucible was used. In most cases, the temperature of the molten silicon was $1873-1973 \mathrm{~K}$, but $1823-1873 \mathrm{~K}$ was adopted with the $300 \mathrm{~kg}$ silicon melt. The bath temperature, which was measured by a thermocouple, was regulated by the control of plasma power.

The MG-Si used in these experiments was partly refined by evaporation and directional solidification by the electron beam method ${ }^{1)}$ (boron, 5-10 mass ppm; phosphorus, below
0.1 mass ppm; iron, aluminum, and titanium, below 10 mass ppm) or semiconductor grade multi-crystalline silicon containing a given amount of boron (boron, 0.730 mass ppm). A small amount of molten silicon was intermittently sampled to identify time changes in the boron content of the melt. Boron contents above 1 mass ppm were analyzed by the ICP (Induced Coupled Plasma) atomic emission spectrometry method; those below 1 mass ppm were analyzed by ICP mass spectrometry. ${ }^{14,15)}$

\section{Experimental Results}

\subsection{Time dependence of boron content}

Figure 2 shows the time dependence of the boron content on the $\mathrm{H}_{2} \mathrm{O}$ content of the added gas without hydrogen with the $0.6 \mathrm{~kg}$ silicon melt. Non-transfer type plasma was used, and the plasma gas was argon. It was found that the logarithmic of boron content decreases linearly with time below a boron content of 0.1 mass ppm.

Figure 3 shows the time dependence of the boron content with the $300 \mathrm{~kg}$ silicon melt. The added gas contents were $\mathrm{H}_{2} \mathrm{O}$, 4.3-4.6 vol\% and $\mathrm{H}_{2}, 50.4-50.6$ vol\%. Non-transfer type plasma was used. In spite of the 500 -fold increase in size of the silicon melt, the boron content decreased linearly, in the same manner as in Fig. 2. Thus, the boron removal rate followed a first-order rate law for boron content.

$$
-\mathrm{d}[B] / \mathrm{d} t=K[B]
$$

where, $t$ is the time (s) and $K$ is the rate constant for the boron removal rate $\left(\mathrm{s}^{-1}\right)$.

Table 2 Experimental conditions.

\begin{tabular}{|c|c|c|c|c|c|}
\hline & \multicolumn{2}{|c|}{ I } & II & III & IV \\
\hline Mass of silicon $/ \mathrm{kg}$ & 0.6 & 2.4 & 7.0 & 20 & 300 \\
\hline Type of plasma & \multicolumn{2}{|c|}{ Non transfer } & $\begin{array}{l}\text { Non transfer } \\
\text { Transfer }\end{array}$ & Non transfer & Non transfer \\
\hline Number of torches & \multicolumn{2}{|c|}{1} & 1 & 2 & 1 \\
\hline $\begin{array}{l}\text { Maximum output of } \\
\text { plasma } / \mathrm{kw}\end{array}$ & \multicolumn{2}{|c|}{30} & 100 & 140 & 650 \\
\hline Plasma gas species & $\mathrm{Ar}, \mathrm{Ar}+\mathrm{He}$ & $\mathrm{Ar}$ & $\mathrm{Ar}$ & $\mathrm{Ar}, \mathrm{Ar}+\mathrm{He}$ & $\mathrm{Ar}+\mathrm{H} 2(15 \mathrm{vol} \%)$ \\
\hline $\begin{array}{l}\text { Flow rate of plasma } \\
\text { Gas, } / \mathrm{Nm}^{3} \mathrm{~s}^{-1}\end{array}$ & $2.5 \times 10^{-4}$ & $2.5 \times 10^{-4}$ & $1.0 \times 10^{-3}-3.7 \times 10^{-3}$ & $3.3 \times 10^{-3}-5.0 \times 10^{-3}$ & $3.7 \times 10^{-2}$ \\
\hline $\mathrm{H}_{2} \mathrm{O}$ flow rate, $/ \mathrm{Nm}^{3} \mathrm{~s}^{-1}$ & $0-4.9 \times 10^{-5}$ & $0-2.7 \times 10^{-5}$ & $5.3 \times 10^{-5}-3.3 \times 10^{-4}$ & $2.2 \times 10^{-4}-9.3 \times 10^{-4}$ & $1.8 \times 10^{-3}-9.5 \times 10^{-3}$ \\
\hline $\mathrm{H}_{2}$ content, $/ \mathrm{Nm}^{3} \mathrm{~s}^{-1}$ & $0-3.8 \times 10^{-4}$ & - & $0-1.7 \times 10^{-3}$ & $0-4.2 \times 10^{-3}$ & $2.7 \times 10^{-2}-3.4 \times 10^{-2}$ \\
\hline $\begin{array}{l}\mathrm{H}_{2} \mathrm{O} \text { content in blown gas onto } \\
\text { silicon melt ( } \mathrm{vol} \% \text { ) }\end{array}$ & $0-7.2$ & $0-9.6$ & $5.0-10.0$ & $5.0-10.0$ & $2.7-14.2$ \\
\hline $\begin{array}{l}\mathrm{H}_{2} \text { content in blown gas onto } \\
\text { silicon melt (vol \%) }\end{array}$ & $0-55.0$ & - & $0-47.0$ & $0-46.5$ & $39.8-51.3$ \\
\hline $\begin{array}{l}\text { Distance between torch tip } \\
\text { and silicon surface, } / \mathrm{m}\end{array}$ & 0.06 & 0.06 & $0.07-0.22$ & $0.08-0.12$ & $0.45-0.55$ \\
\hline Kind of crucible & Silica, Graphite & Silica & Silica & Silica & Silica \\
\hline Inner diameter of crucible,$/ \mathrm{m}$ & 0.07 & 0.115 & 0.28 & 0.40 & 0.62 \\
\hline $\begin{array}{l}\text { Temperature of silicon } \\
\text { melt, } / \mathrm{K}\end{array}$ & $1873-1973$ & $1873-1973$ & $1873-1973$ & $1873-1973$ & $1823-1873$ \\
\hline Heat source for melting & Plasma gas & Plasma gas & Plasma gas & Plasma gas & $\begin{array}{l}\text { Plasma gas, High } \\
\text { frequency induction }\end{array}$ \\
\hline
\end{tabular}




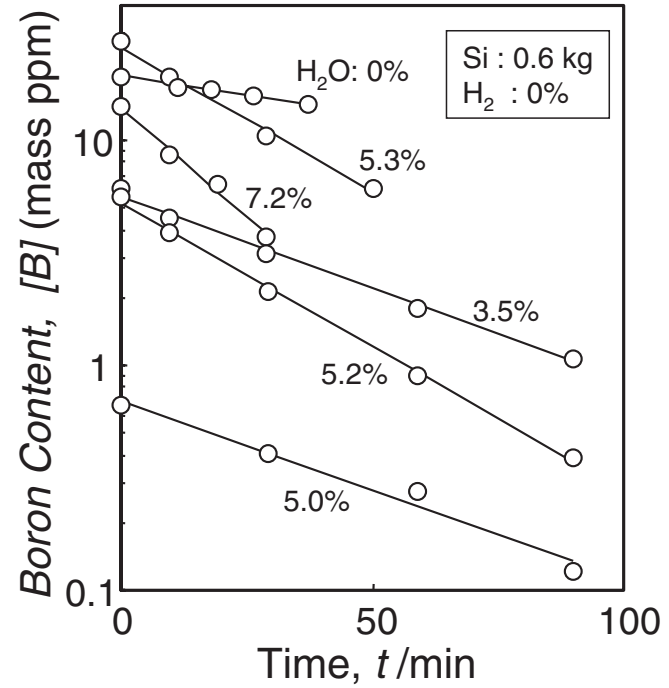

Fig. 2 Time dependence of the boron content for $0.6 \mathrm{~kg} / \mathrm{ch}$-scale experiments.

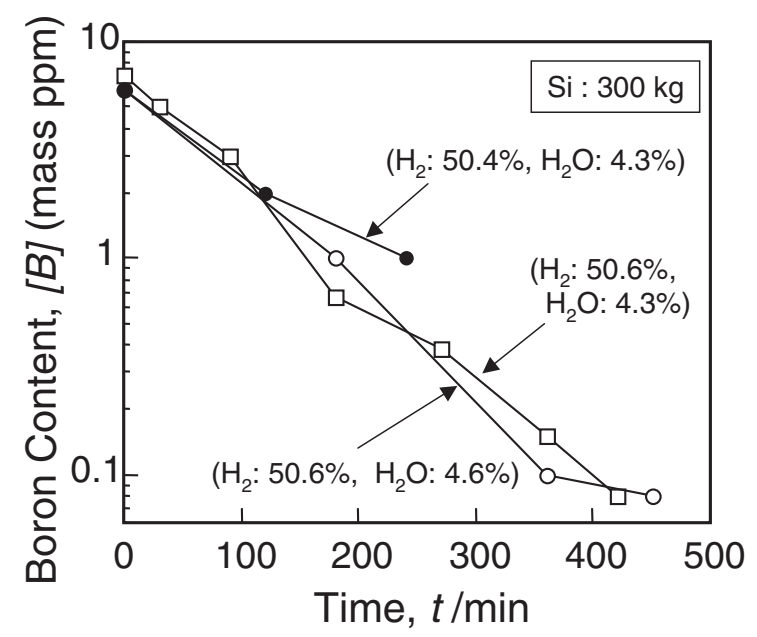

Fig. 3 Time dependence of the boron content for $300 \mathrm{~kg} / \mathrm{ch}$-scale experiments.

\subsection{Effect of interfacial area on boron removal rate}

The diameter and depth of the dimple caused by the impinging plasma jet were measured using a silica bar with the $7 \mathrm{~kg}$ silicon melt. Other conditions were non-transfer plasma, gas content of $\mathrm{H}_{2} \mathrm{O}, 5 \mathrm{vol} \%$ and $\mathrm{H}_{2}, 0 \mathrm{vol} \%$, and distance between the torch tip and surface of the molten silicon, $0.07-0.22 \mathrm{~m}$. The surface area of the dimple caused by the impinging gas was calculated by the method shown in the Appendix. Figure 4 shows the relationship between the rate constant for the boron removal rate and the surface area, $a\left(\mathrm{~cm}^{2}\right)$, of the dimple. $K$ is proportional to $a$, as follows:

$$
K \propto a
$$

This means that the dimple is the reaction interface, which is considered to be reasonable because visual observation showed that the free surface of the molten silicon around the dimple was covered with a silica film.

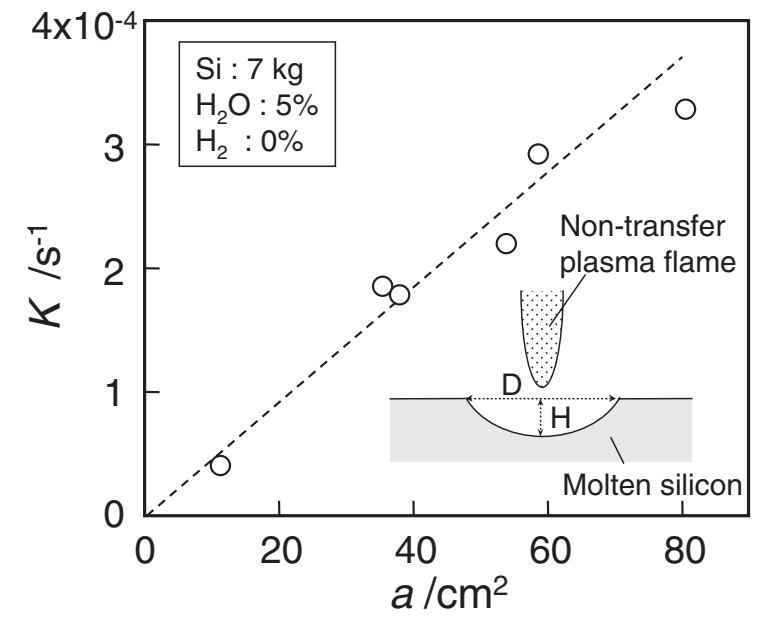

Fig. 4 Relationship between rate constant for deboronization and the surface area of the dimple.

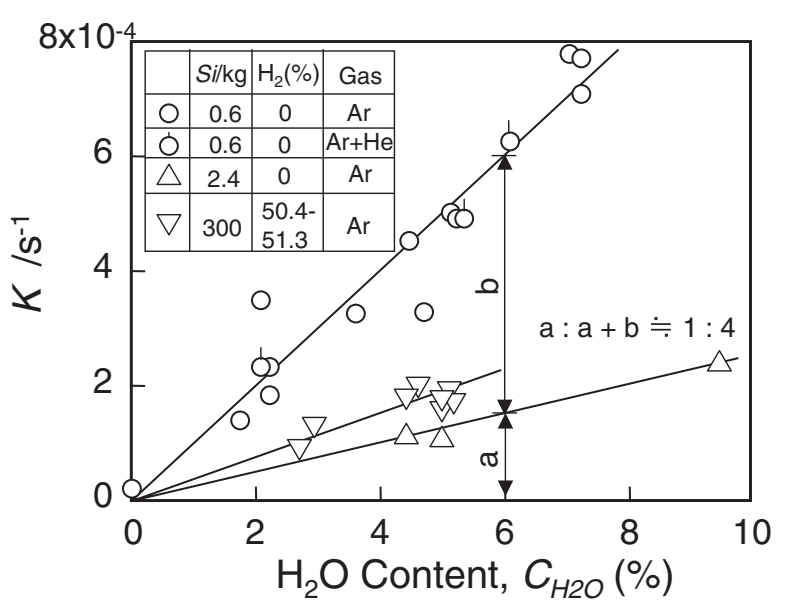

Fig. 5 Relationship between rate constant for deboronization and $\mathrm{H}_{2} \mathrm{O}$ content.

\subsection{Effects of gas composition and species and mass of silicon on boron removal rate}

The relationship between the boron removal rate and hydrogen content is shown in Fig. 5. The masses of silicon used in these experiments were $0.6 \mathrm{~kg}$ and $2.4 \mathrm{~kg}$ without hydrogen addition, and $300 \mathrm{~kg}$ with $50.4-51.3$ vol\% hydrogen. The data for $0.6 \mathrm{~kg}$ and $2.4 \mathrm{~kg}$ of silicon show that the boron removal rate is proportional to the content of added hydrogen at the molten silicon surface and in inverse proportion to the mass of the silicon. Thus, $K$ can be written as follows:

$$
K \propto C_{\mathrm{H}_{2} \mathrm{O}} / V
$$

where $C_{\mathrm{H}_{2} \mathrm{O}}$ is the steam content (vol\%) and $V$ is the volume of the silicon $\left(\mathrm{m}^{3}\right)$.

As seen with the $0.6 \mathrm{~kg}$ silicon melt in Fig. 5, there was no difference in the boron removal rate with argon and helium plasma gases.

Rearranging eqs. (2) and (3), $K$ in eq. (1) can be expressed as shown in eqs. (4) and (5).

$$
-\mathrm{d}[B] / \mathrm{d} t=(k a / V) C_{\mathrm{H}_{2} \mathrm{O}}[B]
$$




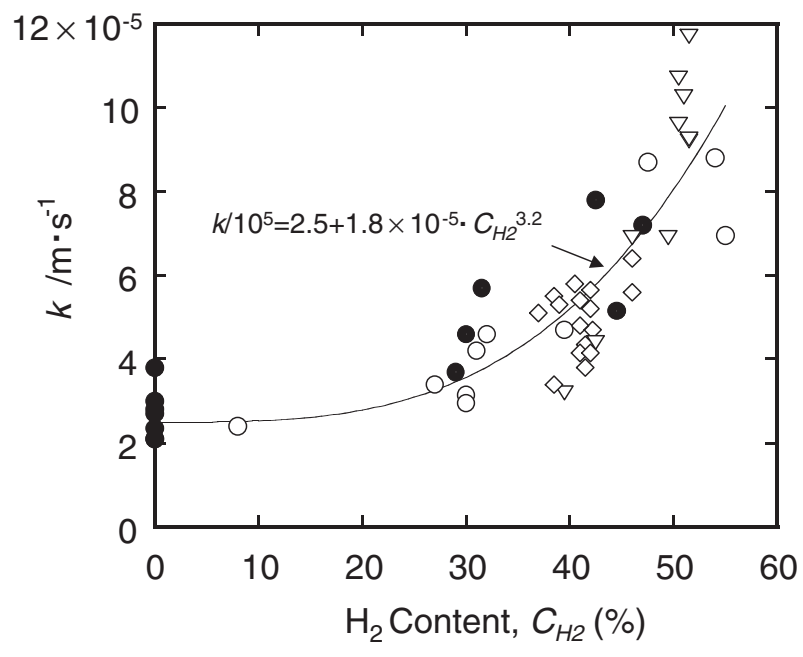

Fig. 6 Relationship between $\mathrm{k}$ and $\mathrm{H}_{2}$ content.

$$
K=(k a / V) C_{\mathrm{H}_{2} \mathrm{O}}
$$

where, $k$ is the overall rate constant of the boron removal reaction.

The relationship between $k$ in eq. (4) and the hydrogen gas content, $C_{\mathrm{H}_{2}}$ (vol\%), is given in Fig. 6, where a is calculated as shown in the Appendix. The boron removal rate increases as the $\mathrm{H}_{2}$ content increases over a wide range of silicon melt sizes between $0.6-300 \mathrm{~kg}$. Expressing $k$ as a multi-regression curve of $k=A+B \times C_{\mathrm{H}_{2}}{ }^{\mathrm{d}}$,

$$
k / 10^{5}=2.5+1.8 \times 10^{-5} \cdot C_{\mathrm{H}_{2}}{ }^{3.2}
$$

where, the correlation factor is 0.87 . Equations (4)-(6) enable calculation of the boron removal rate for given operating conditions and the time required for achieving a given boron content.

$\mathrm{B}_{X} \mathrm{O}_{Y}$ gas was not detected by gas sampling in the furnace. The reason why the boron removal rate increases due to the addition of hydrogen will be discussed in the next chapter.

\subsection{Effect of type of plasma on boron removal rate}

The boron removal rate with a transfer type and nontransfer type plasma was compared using a $7 \mathrm{~kg}$ mass of silicon. The experimental conditions were the same with both types, namely, plasma gas flow rate, $1.7 \times 10^{-3} \mathrm{Nm}^{3} / \mathrm{s}$, distance between the torch tip and free surface of the molten silicon, $0.13 \mathrm{~m}, \mathrm{C}_{\mathrm{H} 2 \mathrm{O}}$ content, $5.0 \mathrm{vol} \%$, and $C_{\mathrm{H}_{2}}$, content, 0 vol $\%$. The dimple areas calculated from the measured values of the dimple diameter and depth were $17 \mathrm{~cm}^{2}$ for the transfer type but $38 \mathrm{~cm}^{2}$ for the non-transfer type. The relationship between $K$ and a is shown in Fig. 7. Under the same operational conditions, the boron removal rate of the non-transfer type plasma was larger than that of the transfer type, mainly due to the larger dimple area with the former. However, there was only a slight difference when the effect of the reaction area was excluded, as seen in Fig. 7.

\section{Discussion}

\subsection{Thermodynamics of boron oxidation}

The oxidation reactions and standard formation energy,

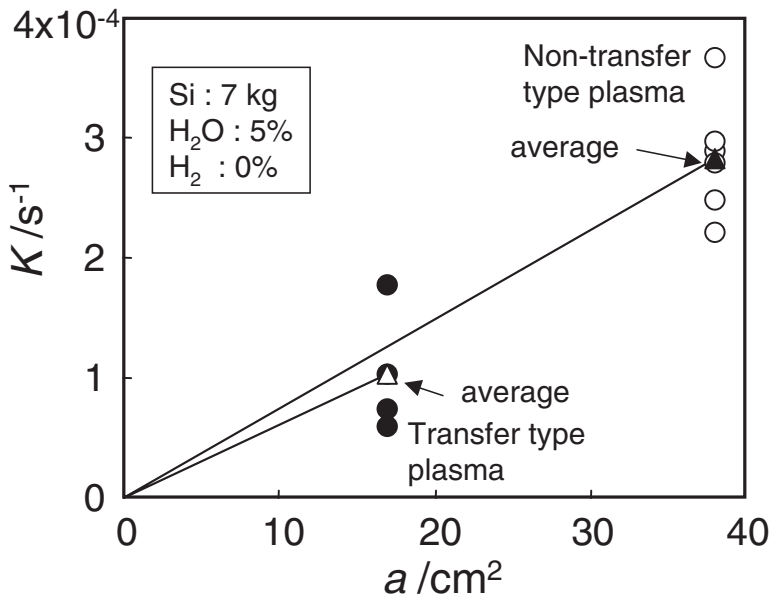

Fig. 7 Comparison of the deboronization rates for melt purification processes with transfer and non-transfer type plasma.

$\Delta G_{\mathrm{j}}$, of steam-boron ${ }^{16)}$ and steam-silicon ${ }^{17)}$ are as follows:

$$
\begin{aligned}
& \mathrm{B}(\mathrm{s})+\mathrm{H}_{2} \mathrm{O}(\mathrm{g})=\mathrm{BO}(\mathrm{g})+\mathrm{H}_{2}(\mathrm{~g}) \\
& \Delta G^{\circ}{ }_{\mathrm{B} / \mathrm{BO}}=-R T \ln \left\{\left(P_{\mathrm{BO}} / a_{\mathrm{B}}\right) /\left(P_{\mathrm{H}_{2} \mathrm{O}} / P_{\mathrm{H}_{2}}\right)\right\} \\
& =8.85 \times 10^{4}-53.2 T \\
& \mathrm{Si}(\mathrm{l})+2 \mathrm{H}_{2} \mathrm{O}(\mathrm{g})=\mathrm{SiO}_{2}(\mathrm{~s})+2 \mathrm{H}_{2}(\mathrm{~g}) \\
& \Delta G^{\circ}{ }_{\mathrm{Si} / \mathrm{SiO}_{2}}=-2 R T \ln \left\{1 /\left(P_{\mathrm{H}_{2} \mathrm{O}} / P_{\mathrm{H}_{2}}\right)\right\} \\
& =4.60 \times 10^{5}-94.1 T
\end{aligned}
$$

where, $R$ is the gas constant $(=8.32451 \mathrm{~J} /(\mathrm{mol} \cdot \mathrm{K})), T$ is the absolute temperature $(\mathrm{K}), P_{\mathrm{BO}}, P_{\mathrm{H}_{2} \mathrm{O}}, P_{\mathrm{H}_{2}}$ are the partial pressures (atm) of $\mathrm{BO}, \mathrm{H}_{2} \mathrm{O}$, and $\mathrm{H}_{2}$, respectively, and $a_{\mathrm{B}}$ is boron activity.

Figure 8 shows the relationship between $P_{\mathrm{H}_{2} \mathrm{O}} / P_{\mathrm{H}_{2}}$ and $T$ as the parameter of $P_{\mathrm{BO}} / a_{\mathrm{B}}$. In order to enhance the boron oxidation reaction in preference to silicon oxidation, the reaction must be between the $\mathrm{Si} / \mathrm{SiO}_{2}$ and $\mathrm{B} / \mathrm{BO}$ equilibrium curves for the given $P_{\mathrm{BO}} / a_{\mathrm{B}}$ values. Preferential boron oxidation is caused by a higher molten silicon temperature, which means that increasing the temperature by plasma heating is more effective than indirect methods which do not affect the reaction surface. In fact, in boron removal

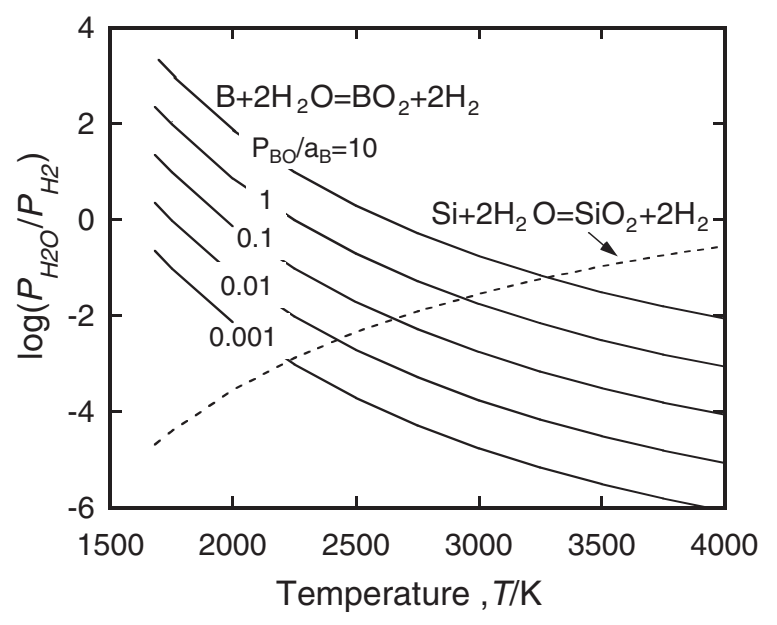

Fig. 8 Equilibrium of $\mathrm{B}(\mathrm{in} \mathrm{Si})-\mathrm{H}_{2} \mathrm{O}-\mathrm{BO}$ and $\mathrm{Si}-\mathrm{H}_{2} \mathrm{O}-\mathrm{SiO}_{2}-\mathrm{H}_{2}$ systems. 
experiments, it was found that supplying gas without plasma heating causes a silica film to form over the dimple. At the same temperature, a smaller $P_{\mathrm{BO}} / a_{\mathrm{B}}$ enhances boron oxidation. On the other hand, because hydrogen addition prevents oxidation of both silicon and boron, as seen in Fig. 8, the accelerated boron removal rate described in section 3.3 cannot be explained by thermodynamics.

When the gas, liquid, and solid phases reach equilibrium for eqs. (7) and (8), the equilibrium partial pressure, $P_{\mathrm{SiO}}$ (atm), of $\mathrm{SiO}$ in the gas phase can be calculated from the following equation. ${ }^{17)}$

$$
\begin{aligned}
& \mathrm{Si}(\mathrm{l})+\mathrm{H}_{2} \mathrm{O}(\mathrm{g})=\mathrm{SiO}(\mathrm{s})+\mathrm{H}_{2}(\mathrm{~g}) \\
& \begin{array}{l}
\Delta G_{\mathrm{Si} / \mathrm{SiO}}^{\circ}=-2 R T \ln \left\{P_{\mathrm{SiO}} /\left(P_{\mathrm{H}_{2} \mathrm{O}} / P_{\mathrm{H}_{2}}\right)\right\} \\
\quad=9.27 \times 10^{4}+8.26 T \log T-1.34 \times 10^{2}
\end{array}
\end{aligned}
$$

Eliminating $P_{\mathrm{H}_{2} \mathrm{O}} / P_{\mathrm{H}_{2}}$ from eqs. (7) and (9) gives eq. (10).

$$
\begin{aligned}
P_{\mathrm{BO}} / P_{\mathrm{SiO}}= & a_{\mathrm{B}} \cdot \exp \left\{\left(\Delta G^{\circ}{ }_{\mathrm{B} / \mathrm{BO}}\right.\right. \\
& \left.\left.-\Delta G^{\circ} \mathrm{Si} / \mathrm{SiO}\right) /(-R T)\right\}
\end{aligned}
$$

where, $a_{\mathrm{B}}$ is given by eq. (11). ${ }^{18)}$

$$
\begin{aligned}
a_{\mathrm{B}} & =\gamma^{\circ}{ }_{\mathrm{B}} X_{\mathrm{B}} \\
& =10^{(-11000 / T+5.82)} \cdot(28.1 / 10.8) \cdot 10^{-6}[\mathrm{~B}]
\end{aligned}
$$

where, $\gamma^{\circ}$ B is the activity coefficient of boron, and $X_{\mathrm{B}}$ is the mole fraction of boron in molten silicon. Assuming that the mole ratio, $(\mathrm{B} / \mathrm{Si})_{\text {dust }}$, of boron to silicon in furnace dust equals $P_{\mathrm{BO}} / P_{\mathrm{SiO}}$, eq. (12) is obtained.

$$
(\mathrm{B} / \mathrm{Si})_{\mathrm{dust}}=P_{\mathrm{BO}} / P_{\mathrm{SiO}}
$$

Figure 9 shows the relationship between the measured (B/ $\mathrm{Si})_{\text {dust }}$ and $X_{\mathrm{B}}$ with a $7 \mathrm{~kg}$ mass of silicon. The relationship can be expressed as follows:

$$
(\mathrm{B} / \mathrm{Si})_{\text {dust }}=36 X_{\mathrm{B}}
$$

This results from a 36-fold enrichment of boron in the gas phase.

Calculating the surface temperature of the molten silicon from eqs. (10) and (13), $T=2700 \mathrm{~K}$ is obtained, whereas the temperature of the bulk silicon in the bath is less than $1973 \mathrm{~K}$. This difference is the result of plasma heating of the free

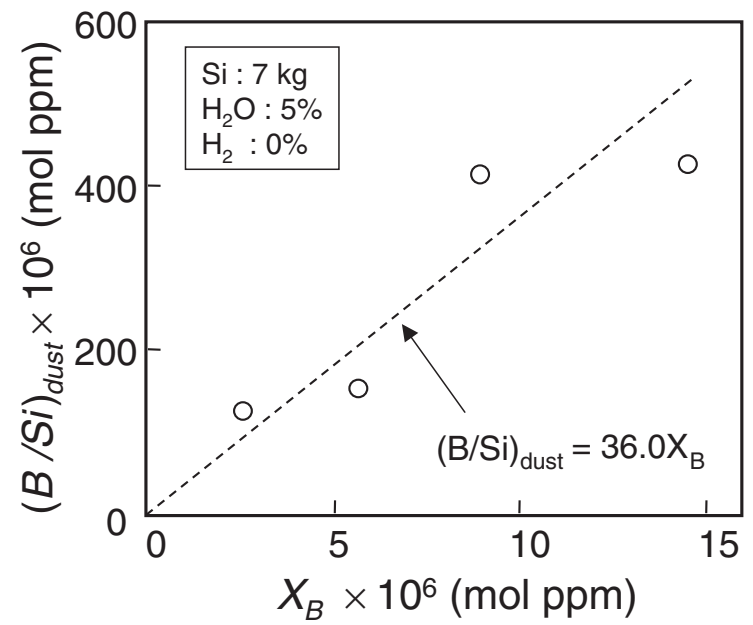

Fig. 9 Relationship between $\mathrm{B} / \mathrm{Si}$ atomic ratio in the silica dust and $\mathrm{B}$ content, $X_{\mathrm{B}}$, of the molten silicon. surface of the molten silicon. As higher temperatures cause preferential oxidation of boron, as discussed above, the steam-added plasma heating method is in principle advantageous in improving boron removal efficiency, compared with the steam injection method shown schematically in Fig. 1.

\subsection{Kinetics of boron oxidation in molten silicon}

The following facts suggest that the chemical reaction between boron and oxygen in molten silicon is the ratedetermining step.

(1) The boron removal rate is proportional to the product of $\left[\mathrm{H}_{2} \mathrm{O}\right]$ and $[\mathrm{B}]$, as shown in section 3.3.

(2) There is no change in the deboronization rate during acceleration of bath agitation by high frequency induction heating.

(3) The deboronization rate does not directly depend on plasma gas flow rate shown in Fig. 4, which suggests that it is not diffusion controlled in the gas phase.

However, in order to prove that the chemical reaction is the rate-determining step, it is necessary to examine the effect of the temperature at the reaction interface on the boron removal rate.

The effect of hydrogen on the boron removal rate could not be explained by the thermodynamics described in section 4.1 . According to visual observation, an $\mathrm{SiO}_{2}$ film formed when the steam content was increased, but disappeared when hydrogen was added. Thus, the reason why the boron removal rate increases as the hydrogen content is increased is estimated to be an increase in the real reaction area due to the reaction $\mathrm{SiO}_{2}+\mathrm{H}_{2} \rightarrow \mathrm{SiO}$. The reaction mechanism of boron removal is shown schematically in Fig. 10.

\section{Application of results to SOG-Si purification process}

Figure 11 shows a schematic representation of the metallurgical process used to produce high-purity SOG-Si from MG-Si. ${ }^{1)}$ This comprises two sequential processes: 1) evaporation of phosphorus ${ }^{3)}$ and elimination of metallic impurities by first directional solidification ${ }^{2)}$ in the electron beam melting furnace, followed by 2) boron oxidation with steam-added plasma, as described here, and elimination of metallic elements by second directional solidification.

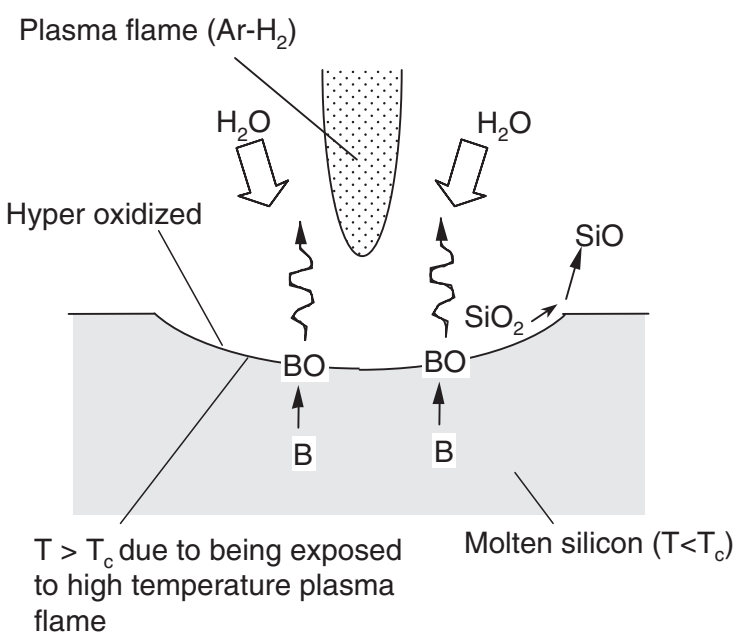

Fig. 10 Estimated deboronization mechanism. 


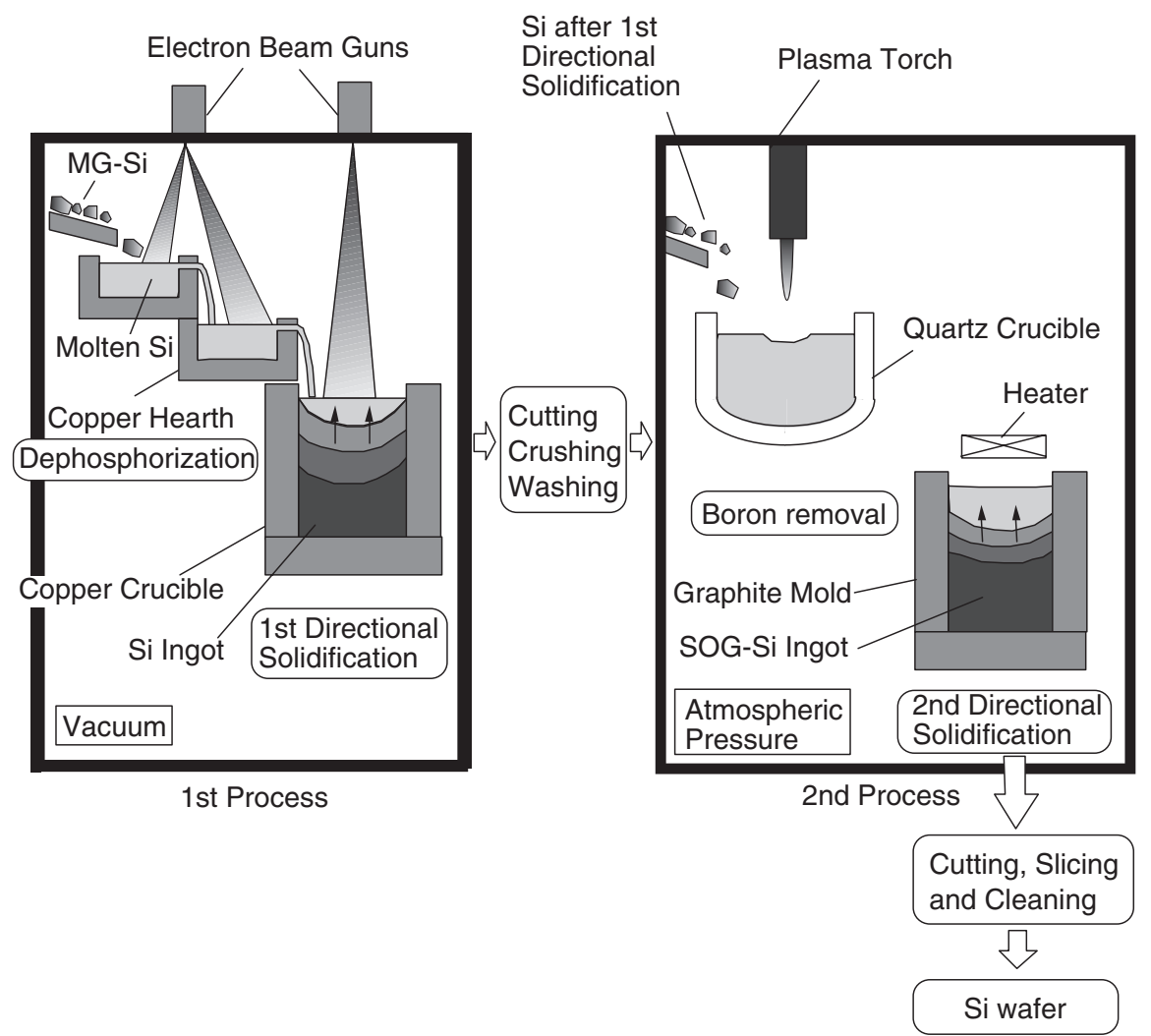

Fig. 11 Schematic view of melt purification process for SOG-Si production.

\section{Conclusions}

Boron removal by steam-added plasma melting occupies an important place in the sequential metallurgical process used to produce high-purity SOG-Si from MG-Si. This study investigated boron removal behavior over a wide range of silicon melt sizes, from silicon masses of 0.6 to $300 \mathrm{~kg}$, the latter being equivalent to an industrial scale production process.

(1) The boron content was consistently reduced to less than 0.1 mass ppm, which is the permissible boron content for SOG-Si for p-type applications.

(2) The boron removal rate is proportional to the steam and boron contents and the area of the dimple caused by the impinging gas jet, and is inversely proportional to the mass of silicon.

(3) The boron removal rate increases as the hydrogen content of the impinging gas is increased.

(4) The boron removal rate with non-transfer type plasma is larger than that with transfer type plasma under the same gas conditions.

(5) A thermodynamic study found that higher bath temperatures accelerate boron oxidation. Thus, as the steamadded plasma method generates a local high temperature area at the reaction interface, it is in principle more effective than other methods.

\section{Acknowledgements}

This work was supported by Japan's New Energy and Industrial Technology Development Organization (NEDO) and Agency of Natural Resources and Energy. The authors wish to thank Prof. Emeritus N. Sano of the University of Tokyo, Prof. T. Saitoh of Tokyo A\&T University, and Dr. F. Aratani of the former SOG-Si Technology Research Association for discussion of technical questions.

\section{REFERENCES}

1) Y. Kato, K. Hanazawa, H. Baba, N. Nakamura, N. Yuge, Y. Sakaguchi, S. Hiwasa and F. Aratani: Tetsu-to-Hagane 86 (2000) 717-724.

2) N. Yuge, K. Hanazawa and Y. Kato: Mater. Trans. 45 (2004) 850-857.

3) K. Hanazawa, N. Yuge and Y. Kato: Mater. Trans. 45 (2004) 844-849.

4) T. Miki, K. Morita and N. Sano: Metall. Trans. B 27B (1996) 937-941.

5) T. Ikeda and M. Maeda: ISIJ Int. 32 (1992) 635-642.

6) F. A. Trumbore: Bell Syst. Tech. J. 39 (1960) 205-233.

7) T. Miki, K. Morita and N. Sano: Metall. Trans. B 28B (1997) 861-867.

8) H. C. Theurer: J. Met. 8 (1956) 1316-1319.

9) P. Humbert, R. Combes, J. Erin, D. Morvan and J. Amouroux: Proc. 10th E.C. Photovoltaic Solar Energy Conf., (Kluwer Academic Publishers, Doldrecht, 1991) pp. 261-266.

10) H. Baba, N. Yuge, Y. Sakaguchi, F. Aratani and Y. Habu: Proc. 10th E.C. Photovoltaic Solar Energy Conf., (Kluwer Academic Publishers, Doldrecht, 1991) pp. 286-290.

11) K. Suzuki, K. Sakaguchi, T. Nakagiri and N. Sano: J. Japan Inst. Metals 54 (1990) 161-167.

12) K. Suzuki, K. Kumagai and N. Sano: ISIJ Int. 32 (1992) 630-634.

13) T. Ikeda and M. Maeda: Mater. Trans., JIM 37 (1996) 983-987.

14) K. Fujimoto and T. Okano: Bunseki Kagaku 42 (1993) T135-T142.

15) K. Fujimoto, M. Ito, M. Shimura and K. Yoshioka: Bunseki Kagaku 47 (1998) 187-193.

16) JANAF Thermochemical Tables, 3rd Ed., ed. by M. W. Chase, Jr. et al., (ACS and AIP for NBS, New York, 1985) p. 118.

17) O. Kubaschewski and C. B. Allock: Metallurgical Thermochemistry, 5th Ed., (Pergamon Press, New York, 1979) p. 359.

18) R. Noguchi, K. Suzuki, F. Tsukihashi and N. Sano: Metall. Trans. B 25B (1994) 903-907. 


\section{Appendix: Method of estimating surface area of dimple caused by impinging gas jet}

Segawa gave the following equation, ${ }^{\mathrm{A} \cdot 1)}$ for the dimple depth, $L(\mathrm{~m})$, caused by an impinging gas jet, for given values of the distance, $h(\mathrm{~m})$, between the torch tip and free surface, inner diameter of the mold, $d(\mathrm{~m})$, gas velocity, $v(\mathrm{~m} / \mathrm{s})$, gas density, $\rho_{\mathrm{g}}\left(\mathrm{kg} / \mathrm{m}^{3}\right)$, density of molten silicon, $\rho_{\mathrm{l}}\left(\mathrm{kg} / \mathrm{m}^{3}\right)$, and $a$ constant, $C^{\prime}$.

$$
(L+h) \cdot L^{1 / 2}=C^{\prime} v d\left(\rho_{\mathrm{g}} / \rho_{\mathrm{l}}\right)^{1 / 2}
$$

where, $\quad v d\left(\rho_{\mathrm{g}}\right)^{1 / 2}$ is proportional to $T^{1 / 2}$, that is, $\{(1-\eta) P / Q\}^{1 / 2}$, in which $Q$ is the plasma gas flow rate $\left(\mathrm{Nm}^{3} / \mathrm{min}\right), P$ is the power loss rate of the plasma torch due to water cooling vs. input power $(\mathrm{kW})$, and $T$ is the gas temperature (K). Thus, eq. (A·1) can be rewritten as

$$
(L+h) \cdot L^{1 / 2}=C\{(1-\eta) P / Q\}^{1 / 2} v_{0} \mathrm{~d}
$$

where, $v_{0}$ is the gas velocity $(\mathrm{Nm} / \mathrm{s})$ at the torch tip in the standard state.
The dimple depth for given values of $P, Q, h$, and d can be calculated from eq. (A-2).

Here, $C$ is estimated to be $5.4 \times 10^{-3}$, substituting the measured value from the experiment with a $7 \mathrm{~kg}$ mass of silicon at $Q=0.1 \mathrm{Nm}^{3} / \mathrm{min}$ without hydrogen addition.

Considering expansion of the gas jet, the dimple diameter, $D(\mathrm{~m})$, was assumed to be as follows:

$$
D=d+2 \tan \theta
$$

where, $\theta$ is the expansion angle $\left(=10_{0}\right)$.

The surface area, $\mathrm{s}\left(\mathrm{m}^{2}\right)$, of the dimple eventually is approximated by the surface area of a rotating ellipsoidal body.

$$
\begin{aligned}
& s=(4 / 3) \pi a\left[\left\{(L / a)+\left(1 / 4 a^{2}\right)\right\}^{3 / 2}-\left(1 / 8 a^{3}\right)\right] \\
& a=4 L / D^{2}
\end{aligned}
$$

\section{REFERENCES}

A1) K. Segawa, Tetsuyakin han-nokogaku, (Nikkan Kogyo Simbunsha, Tokyo, 1977) pp. 90-94. 